\title{
PENGEMBANGAN MODEL PEMBELAJARAN MATEMATIKA BERBASIS PORTOFOLIO (PMBP) PADA SISWA SEKOLAH MENENGAH PERTAMA
}

\author{
Zainal Abidin', Zulkifley Mohamed $^{2}$, Sazelli Abdul Ghani ${ }^{3}$ \\ ${ }^{1}$ Program Studi Pendidikan Matematika, Universitas Islam Malang, Indonesia \\ ${ }^{2,3}$ Departemen Pendidikan Matematik, Universiti Pendidikan Sultan Idris, Malaysia \\ 1e-mail: zainal_abid@yahoo.co.id
}

\begin{abstract}
Abstrak
Penelitian ini bertujuan menghasilkan model pembelajaran matematika berbasis portofolio untuk meningkatkan hasil belajar siswa Sekolah Menegah Pertama (SMP). Penelitian ini merupakan penelitian pengembangan (development research), dengan langkah-langkah pengembangan: (1) investigasi awal (preliminary investigation) atau kajian awal; (2) rancangan (design); (3) realisasi/konstruksi (realization/construktion); (4) uji validasi ahli, uji coba (kepraktisan dan keefektifan), revisi; dan (5) implementasi (implementation). Hasil kajian menunjukkan bahwa hasil pengembangan model pembelajaran matematika berbasis portofolio pada siswa SMP memenuhi kriteria kualitas produk (model) yang valid, praktis, dan efektif. Hasil implementasi model menunjukkan bahwa model pembelajaran matematika berbasis portofolio dapat meningkatkan hasil belajar matematika siswa SMP. Hasil kajian ini dapat dipertimbangkan untuk dipergunakan sebagai model alternatif dalam pelaksanaan pembelajaran persamaan linear dua variabel di SMP.
\end{abstract}

Kata Kunci: pengembangan, model pembelajaran, portofolio matematika, hasil belajar

\section{PENDAHULUAN}

Keberhasilan pembelajaran dipengaruhi oleh beberapa faktor (komponen) yaitu guru, siswa, prasarana dan lingkungan (Sanjaya, 2008). Guru merupakan komponen yang paling penting dan menentukan, karena guru merupakan orang yang secara langsung berhadapan dengan siswa di dalam proses pembelajaran. Dalam proses pembelajaran, guru berperan sebagai perancang (planer dan designer), sebagai yang melaksanakan (implementator) atau sebagai keduanya. Keefektifan proses pembelajaran menjadi tanggung jawab guru. 
Keberhasilan suatu proses pembelajaran ditentukan oleh kemampuan dan keprofesionalan guru dalam mengelola proses pembelajaran (Sanjaya, 2008; Rusman, 2012).

Untuk memperoleh hasil yang maksimum dalam proses pembelajaran, diperlukan model pembelajaran. Proses pembelajaran yang efektif tidak dapat dipisahkan dengan model atau strategi pembelajaran yang dijalankan oleh guru di sekolah. Keefektifan suatu model atau strategi pembelajaran dapat dicapai model atau strategi tersebut dengan mendorong siswa dalam pemerolehan dan pemahaman materi pelajaran (Jacobsen dkk, 2009).

Pembelajaran matematika di Indonesia belum menunjukkan hasil yang diharapkan. Hasil tinjauan yang dilakukan oleh berbagai pihak, baik yang berskala internasional maupun skala nasional menunjukan hasil pembelajaran matematika yang masih belum memuaskan. Hasil tinjauan TIMSS (Trends in International Mathematics and Science Study) pada tahun 2011, menunjukkan prestasi matematika siswa Indonesia berada pada tahap ke-35 dari 49 negara (Depdikbud, 2012b). Hal ini menunjukkan bahwa prestasi matematika untuk siswa Indonesia di peringkat internasional masih belum menggembirakan. Prestasi pembelajaran matematika secara nasional juga tidak jauh berbeda dengan hasil tinjauan oleh TIMSS. Pengukuran terhadap prestasi belajar di Indonesia dilakukan dengan menggunakan instrumen Ujian Nasional (UN). Skor Hasil UN yang diperoleh di Sekolah Menengah Pertama (SMP) tahun 2011 di Kota Malang Indonesia, pelajaran Bahasa Indonesia mendapat skor rata-rata 7.68, pelajaran IPA mendapat skor rata-rata 7.12, pelajaran Bahasa Inggris mendapat skor rata-rata 7.03, dan pelajaran Matematika mendapat skor rata-rata 6.51 (Malang Post, 2011). Berdasarkan hasil UN tersebut, pelajaran matematika memperoleh hasil yang paling rendah. Ini menunjukkan bahwa prestasi matematika untuk siswa Indonesia secara nasional di Kota Malang juga masih belum menggembirakan.

Sebagian faktor yang menjadi penyebab rendahnya perolehan skor UN matematika adalah disebabkan oleh guru. Persoalan yang sering dihadapi dalam pembelajaran matematika di sekolah, umumnya adalah matematika dirasakan sebagai pelajaran yang tidak diminati oleh banyak siswa (Turmudi, 2009a). Menurut siswa, matematika adalah pelajaran yang sulit dan tidak menarik disebabkan oleh guru yang mengajarkan matematika menggunakan model, pendekatan, strategi atau metode yang tidak menarik. Sewaktu melaksanakan aktivitas pembelajaran guru menggunakan model pembelajaran yang tidak sesuai dengan materi yang diajarkan. Mayoritas guru menggunakan model konvensional dalam melaksanakan aktivitas pembelajaran, model pembelajaran yang mengedapankan guru sebagai sumber utama informasi. Model pembelajaran yang dijalankan guru dalam proses pembelajaran sekarang ini kurang memperhatikan keterlibatan siswa secara aktif (Hudoyo, 2005; Soedjadi, 2010; Marpaung, 2003; Pambudi, 2007; Trianto, 2011; Muslich, 2009; Suyono, 2012).

Keaktifan siswa dalam proses pembelajaran matematika adalah sangat penting. Menurut NCTM (2000) dan Walle (2012), standard profesional pembelajaran matematika adalah pembelajaran yang berpusat kepada siswa, yang lebih mengaktifkan siswa. Menurut Jacobsen dkk (2009), keefektifan suatu model atau strategi pembelajaran dapat dicapai 
dengan menerapkan model atau strategi pembelajaran yang dapat mendorong siswa dalam pemerolehan dan pemahaman materi pelajaran (pengetahuan).

Hiebert dan Carpenter (1992) dan Walle (2012) menyatakan bahwa dalam pembelajaran matematika, siswa perlu memahami matematika. Untuk mengkonstruksi atau memahami pengetahuan memerlukan pemikiran yang aktif (Glaserfeld,1996; Walle, 2012). NCTM (2000) dan Turmudi (2009b) menguatkan pernyataan tersebut bahwa para siswa harus belajar matematika dengan pemahaman, secara aktif membagun pengetahuan baru dari pengalaman dan pengetahuan sebelumnya, sedangkan tugas guru adalah mendorong siswa untuk berfikir, bertanya, menyelesaikan soal, mendiskusikan idea-idea, strategi dan penyelesaiannya.

Menurut Jacobsen dkk (2009), dalam pembelajaran berpusat kepada siswa, selain konstruktivistik juga menyarankan aktivitas-aktivitas yang di dalamnya siswa diberikan otonomi (kemandirian) dan kontrol yang luas untuk mengarahkan aktivitas-aktivitas yang meliputi penyelesaian masalah, bekerja dalam bentuk kelompok kecil, pembelajaran kolaboratif, kerja investigatif dan pembelajaran eksperiential. McCombs dan Miller (2007) menambahkan, dalam pembelajaran yang berpusat kepada siswa, guru hendaknya menempatkan perhatian yang lebih banyak kepada keterlibatan, inisiatif, dan interaksi sosial. NCTM (2000) dan Walle (2012) menyatakan bahwa dalam pembelajaran matematika, supaya siswa dapat mengembangkan kemampuan matematikanya maka guru perlu diantaranya: (1) mementingkan membuat dugaan, penelitian (inkuiri) dan penyelesaian masalah (soal), (2) mengaitkan matematika (misalnya dengan alam lingkungannya, benda-benda nyata), ideaidea dan aplikasinya serta tidak memperlakukan matematika sebagai kumpulan konsep dan prosedur yang terpisahkan. Untuk mendorong keberhasilan siswa, Kilpatrick dkk (2001) menyarankan dua hal yaitu: (1) perancangan tugas-tugas yang memungkinkan siswa menyelesaikannya dan siswa berusaha sungguh-sungguh; dan (2) pemberian bantuan (scaffolding) apabila diperlukan untuk membantu siswa menyerap dan menerapkan konsepkonsep.

Hal-hal lain yang dapat mempengaruhi hasil belajar siswa antara lain tingkat berfikir siswa dan sifat (karakteristik) dari matematika. Menurut Piaget, anak-anak berfikir dan bertindak tidak sama seperti orang dewasa. Setiap individu mengalami tingkatan periode perkembangan berfikir (intelektual), yaitu periode sensori motor (0- 2 tahun), pra-operasional (2-7 tahun), operasi kongkrit (7-11 tahun), dan operasi formal (11 tahun ke atas) (Saad \& Ghani, 2010; Slavin, 2011; Arends; 2007; Dahar, 2011; Hudoyo, 2005; Budiningsih, 2005; Suherman, 2001; Muhsetyo, 2008; Suparno, 2012; Yamin, 2012; Yaumi, 2013). Hal ini menunjukkan bahwa perkembangan berfikir anak-anak berbeda dengan orang dewasa. Oleh karena itu, guru harus mengembangkan kemampuan berfikir atau intelektual siswa sesuai dengan perkembangan intelektualnya. Model, pendekatan dan strategi pembelajaran matematika yang digunakan harus disesuaikan dengan kondisi yang berkaitan kemampuan berfikir siswa yang akan memungkinkan efisiensi dan keefektifan dari usaha-usaha dalam pembelajaran matematika. 
Menurut Hudoyo (2005) dan Karso (2008), sifat materi matematika merupakan materi yang berkenaan gagasan abstrak yang tersusun secara hierarki, adanya kesepakatan, penalaran bersifat deduktif, aksiomatik, dan berstruktur. Hal ini dapat membawa dampak kepada bagaimana terjadinya proses pembelajaran materi matematika. Jika model pembelajaran yang dijalankan tidak sesuai atau tidak tepat maka dapat menyebabkan siswa merasa sulit dan tidak senang belajar matematika. Soedjadi (2003) menyatakan bahwa sifat matematika yang abstrak tersebut dapat menjadikan kendala seorang guru dalam memahamkan materi matematika yang diberikan kepada siswa. Hal ini menjadi tantangan guru untuk dapat melaksanakan pembelajaran yang efektif.

Karena sifat materi matematika merupakan materi yang berkaitan gagasan abstrak yang tersusun secara hierarki, penalarannya deduktif, dan aksiomatik maka materi matematika menuntut kemampuan siswa untuk berfikir. Menurut Hudoyo (2005) dan Kemendibud (2013b), pelajaran matematika pada pendidikan menengah di Indonesia telah menuntut kemampuan berfikir formal. Karena sifat matematika memiliki objek yang berkaitan gagasan abstrak, pola penalaran deduktif, dan aksiomatik maka siswa akan mudah mempelajari pelajaran matematika di tingkat sekolah menengah jika siswa telah mencapai kemampuan berfikir formal. Tetapi menurut MacKinnon (2004) masih banyak siswa yang sampai lulusan sekolah menengah belum mencapai tahap berfikir formal. Oleh karena itu, guru harus memperhatikan tingkat berfikir siswa dalam memilih model, pendekatan, strategi atau metode yang digunakan dalam pembelajaran matematika sehingga siswa dengan mudah menggunakan penalarannya dalam memahami pelajaran matematika.

Memperhatikan keadaan di atas perlu diatasi dengan mengusahakan perbaikan pembelajaran dengan mengubah pandangan terhadap pembelajaran yang memandang guru yang lebih aktif menjadi pandangan tentang siswa yang lebih aktif. Selain itu, untuk menjadikan pembelajaran matematika lebih diminati, disenangi siswa, dan mudah difakami siswa maka pembelajaran matematika tidak dapat dipisahkan dengan pengalaman dan lingkungan kehidupan nyata (kongkret) sehari-hari siswa. Pembelajaran yang menjadikan pengalaman dan lingkungan sekeliling siswa dalam proses pembelajaran akan dapat membantu siswa untuk meningkatkan minat, motivasi dan pemahaman matematika siswa (Allsopp dkk, 2007).

Untuk mengatasi masalah pembelajaran matematika sebagaimana diuraikan dia atas, maka pada kajian ini dikembangkan model pembelajaran matematika yang berbasis portofolio yang dapat mengaktifkan siswa, dapat mendorong pemerolehan dan pemahaman materi pelajaran matematika dengan aktivitas-aktivitas penyelesaian tugas-tugas berorientasi soal (masalah), belajar dalam bentuk keompok secara kooperatif, eksperiential (pengalaman), penelitian (inkuiri), dan yang kontekstual (mengaitkan dengan lingkungan kehidupan nyata seharian) serta menyenangkan.

Menurut Budimansyah (2002), portofolio dapat diartikan sebagai suatu wujud benda fisik, sebagai suatu proses sosial pedagogi, maupun sebagai adjective. Sebagai wujud benda fisik, portofolio adalah bundel, yaitu kumpulan pekerjaan siswa. Sebagai suatu proses sosial 
pedagogi, portofolio adalah kumpulan pengalaman pembelajaran (collection of learning experience) yang terdapat di dalam fikiran siswa baik yang berwujud pengetahuan (kognitif), keterampilan (skill), maupun sikap (afektif). Sebagai suatu adjective, portofolio sering dijajarkan dengan konsep lain, misalnya konsep "pembelajaran" dan "penilaian". Jika dijajarkan dengan pembelajaran maka dikenal dengan istilah pembelajaran berbasis portofolio (portofolio based learning), sedangkan jika dijajarkan dengan penilaian maka dikenal istilah penilaian berbasis portofolio. Dalam kajian ini, portofolio berkaitan dengan pembelajaran yaitu pembelajaran matematika berbasis portofolio (PMBP).

Portofolio matematika merupakan suatu kumpulan pengalaman belajar siswa melalui rangkaian tugas matematika yang membahas suatu masalah (soal) yang dapat menghasilkan pengetahuan (kognitif), keterampilan ( $k$ ill), dan sikap (afektif) berkaitan matematika sesuai tujuan pembelajaran yang diharapkan. Sedangkan model pembelajaran matematika berbasis portofolio (PMBP) adalah model pembelajaran yang memberikan pengalaman-pengalaman belajar siswa melalui suatu rangkaian tugas matematika yang membahas suatu masalah (soal) yang dapat menghasilkan pengetahuan (kognitif), keterampilan (skill), dan sikap (afektif) berkaitan matematika untuk mencapai tujuan pembelajaran yang diharapkan.

Model pembelajaran adalah kerangka konseptual yang menggambarkan prosedur yang sistematis dalam mengorganisasikan (menyusun) pengalaman belajar siswa untuk mencapai tujuan belajar. Model pembelajaran matematika berbasis portofolio merupakan model pembelajaran matematika yang menggunakan portofolio matematika sebagai inti atau fokus aktivitas pembelajaran untuk mencapai tujuan pembelajaran. Dalam pembelajaran matematika berbasis portofolio menggunakan tugas-tugas beorientasi masalah matematika sebagai langkah awal dalam mengumpulkan dan menggabungkan pengetahuan baru berdasarkan pengalamannya dalam beraktivitas dan menuntut siswa untuk melakukan aktivitas merancang, menyelesaikan tugas (masalah), melakukan aktivitas-aktivitas eksplorasi, investigasi, penelitian (inkuiri) dan mengolah informasi serta memberikan peluang kepada siswa untuk bekerja secara mandiri maupun kelompok.

Dalam implementasinya, model pembelajaran matematika berbasis portofolio merupakan model pembelajaran yang berlandaskan pada teori konstruktivistik yang mengaktifkan siswa (berpusat kepada siswa), berfokus kepada soal-soal tugas (penyelesaian masalah/soal), pembelajaran yang melibatkan siswa bekerja sama dalam kelompok (kooperatif), pembelajaran yang mengaitkan matematika dengan lingkungan siswa (kontekstual), pembelajaran melalui pengalaman (eksperiential), pembelajaran inkuri (penelitian) dan pembelajaran yang menyenangkan.

Model pembelajaran matematika berbasis portofolio menerapkan teori belajar konstruktivistik yang dikembangkan Piaget dan Vygotsky. Konsep pembelajaran konstruktivistik merupakan pembelajaran yang didasarkan pada pemahaman bahwa proses belajar yang dilakukan siswa merupakan proses konstruksi pengetahuan, pemahaman dan pengalaman yang dilakukan oleh siswa secara individu atau kelompok. Penerapan konstruktivistik dalam pembelajaran, berarti menempatkan siswa sebagai pusat pembelajaran, 
sedangkan guru dituntut menjadi pemudah cara yang baik, yang dapat menggali potensi yang dimiliki siswa. Menurut teori konstruktivistik Piaget, pembelajaran dilakukan dengan memusatkan perhatian kepada berfikir atau proses mental siswa, tidak sekedar kepada hasilnya, dan mengutamakan peran siswa dalam aktivitas pembelajaran (Slavin, 2011; Arends; 2007; Suprihatiningrum, 2012; Riyanto, 2009; Saad \& Ghani, 2010).

Sedangkan berdasarkan teori konstruktivistik Vygotsky, dalam pembelajaran perlu dilakukan melalui interaksi sosial. Peranan interaksi sosial merupakan hal yang penting. Seseorang dapat merekonstruksi pengetahuan yang telah dimiliki sebelumnya melalui aktivitas interaksi sosial. Vygotsky memandang bahwa dengan mengadakan perbincangan atau mendengarkan pendapat orang (siswa) lain akan membentuk pengetahuan atau mengubah pengetahuan yang telah dimiliki sebelumnya (Slavin, 2011; Arends; 2007; Muhsetyo, 2008; Suprihatiningrum, 2012; Budiningsih, 2005; Suyono, 2012; Yamin, 2012; Yaumi, 2013). Jika seseorang siswa tidak dapat melakukan suatu pekerjaan (tugas matematika) dengan pengetahuan yang telah dimilikinya, kemudian bertanya kepada siswa lain (pada waktu berinteraksi sosial), maka siswa akan memperoleh pengetahuan baru. Dengan pengetahaun baru ini siswa dapat menyelesaikan soal-soal atau tugas-tugas yang sebelumnya tidak dapat diselesaikan.

Dalam implementasi model PMBP berfokus pada soal-soal tugas (penyelesaian masalah/soal). Siswa perlu dilibatkan dalam berbagai proyek (tugas) yang berorientasi masalah dan membantu siswa menyelidiki berbagai masalah (Arends, 2007). Matematika seharusnya diajarkan melalui penyelesaian masalah (soal) (Walle, 2012), dan penyelesaian masalah (soal) semestinya tidak dipisahkan dari program pembelajaran matematika (NCTM, 2000). Pembelajaran berdasarkan masalah dapat meningkatkan motivasi dan rasa ingin tahu siswa karena dalam pembelajaran ini terdapat tantangan, tugas otentik dan keterlibatan siswa (Eggen \& Kauchak, 2012). Dengan model PMBP dapat membantu siswa untuk mengembangkan keterampilan berfikir, keterampilan mengatasi masalah, melatih siswa menjadi mandiri, meningkatkan motivasi dan rasa ingin tahu siswa serta memperoleh berbagai pengalaman belajar.

Model PMBP dijalankan dengan melibatkan siswa bekerja sama dalam kelompok (kooperatif). Dengan pembelajaran secara kooperatif, siswa akan lebih mudah menemukan dan memahami konsep yang sulit jika siswa dapat berbicara satu dengan yang lain tentang suatu masalah (Slavin, 2011). Dengan secara kooperatif, siswa dapat mengembangkan kemahiran bekerja sama dan kemahiran menyelesaikan tugas-tugas (Johnson \& Johnson, 2006). Dengan pembelajaran secara kooperatif, memungkinkan sharing atas perspektifperspektif alternatif, membantu siswa melihat gagasan-gagasan dengan cara-cara yang berbeda, juga memungkinkan siswa untuk mengkontruksi pengetahuan dan memberdayakan gagasan orang-orang lain (Eggen \& Kauchak, 2007). Dengan model PMBP siswa dapat menyelesaikan tugas-tugas atau soal-soal dengan saling beriterakasi atau bekerja sama sehingga memperoleh pemahaman matematika.

Dalam model PMBP mengaitkan materi matematika yang dipelajari dengan kehidupan 
lingkungan siswa sehari-hari dengan tujuan supaya pembelajaran lebih bermakna untuk siswa. Pembelajaran matematika berbasis portofolio menerapkan pembelajaran kontekstual. Dengan pembelajaran kontekstual atau mengaitkan materi yang dipelajari dengan kehidupan nyata sehari-hari siswa dapat menemukan makna pelajaran untuk kehidupan siswa (Komalasari, 2010; Johnson, 2002).

Model PMBP merupakan bentuk pembelajaran melalui pengalaman (eksperiential). Implementasi model PMBP sebagai usaha untuk mendekatkan siswa kepada subjek yang dibahas. Pembelajaran yang paling baik adalah jika siswa secara individu terlibat dalam pengalaman belajarnya, pengetahuan perlu ditemukan siswa sendiri supaya memiliki arti atau dapat membuat perubahan tingkah laku siswa, dan kesungguhan siswa secara aktif dalam mencapai tujuan pembelajaran (Johnson \& Johnson, 2006; Arends, 2007). Dengan berusaha untuk mencari penyelesaian masalah secara mandiri atau kelompok akan memberikan suatu pengalaman konkret, dengan pengalaman tersebut dapat digunakan pula menyelesaikan masalah-masalah serupa, karena pengalaman itu memberikan makna tersendiri bagi siswa (Hudoyo, 2005). Melalui model PMBP, siswa memperoleh pengalaman secara fisik terhadap objek dalam pembelajaran dan memperoleh pengalaman (terlibat) secara mental.

\section{METODE}

Jenis penelitian ini adalah penelitian pengembangan (development research). Penelitian pengembangan digunakan untuk mengembangkan dan menguji/menilai produk tertentu (Sugiyono, 2011; Sugiyono, 2013; Borg \& Gall, 1989). Penelitian ini menggunakan desain penelitian pengembangan yang diadaptasi dari Plomp (1997), yang didasarkan pada pertimbangan bahwa model tersebut merupakan model yang bersifat umum yang dapat digunakan untuk pengembangan model pembelajaran dan mudah dijalankan. Dalam penelitian ini, tahapan yang dijalankan adalah: (1) Investigasi Awal (Preliminary Investigation) atau kajian awal; (2) Perancangan (design), (3) Realisasi/Konstruksi (realization/ construction); (4) Uji Validasi ahli, Uji coba (uji kepraktisan dan uji keefektifan), dan Revisi; dan (5) Implementasi (implemenatation).

Untuk menilai kualitas produk model pembelajaran mengikuti kriteria Nieveen (1999), yaitu krteria valid, praktis, dan efektif. Untuk menilai kevalidan dilakukan melalui penilaian ahli, sedangkan menilai kepraktisan dan keefektifan dilakukan melalui uji coba produk (uji lapangan). Komponen-komponen yang tercakup dalam model pembelajaran mengikuti konsep model Joyce dan Weil (2009), yaitu: (a) sintaks model; (b) sistem sosial; (c) prinsip reaksi; (d) sistem pendukung; dan (e) dampak instruksional dan pengiring.

Dalam penelitian ini yang menjadi subjek adalah siswa kelas delapan SMP Wahid Hasyim Malang Indonesia sebagai tempat pelaksanaan uji coba (uji lapangan) pengembangan model PMBP dan implementasi model PMBP. Responden dalam kajian ini adalah guru yang mengabdi di sekolah tersebut dengan kualifikasi lulusan jurusan pendidikan matematika 
dan dibantu oleh dua observer. Materi menjadi yang objek penelitian adalah persamaan linear dua variabel.

Pengambilan subjek di SMP Wahid Hasyim Malang ini didasarkan kepada: (1) di Propinsi Jawa Timur terdapat 38 kota dan dari hasil Ujian Nasional tahun 2012 di Kota Malang rata-rata nilai matematika masuk peringkat ke 30 atau peringkat rendah. Di Kota Malang terdapat 90 SMP yang dapat dikelompokkan tiga peringkat yaitu atas, sedang dan bawah dan SMP Wahid Hasyim Malang termasuk peringkat bawah (http://www.diknas.malangkota.go.id). Penelitian ini dijalankan di SMP Wahid Hasyim Malang diharapkan hasil dari kajian pengembangan model pembelajaran matematika ini dapat dijalankan untuk meningkatkan kualitas pembelajaran matematika di sekolah tersebut dan sekolah-sekolah lain, sehingga hasil kajian ini dapat memberikan sumbangan penerapan model pembelajaran dalam aktivitas pembelajaran matematika; (2) Siswa kelas delapan dijadikan subyek untuk penelitian ini karena telah melalui waktu peralihan yaitu peralihan dari pembelajaran sekolah dasar di kelas tujuh. Siswa kelas delapan dapat dikatakan telah bebas dari faktor gangguan seperti masalah emosi yang dapat mempengaruhi hasil penelitian. Siswa kelas delapan juga tidak merupakan kelas ujian seperti siswa kelas sembilan. Dengan demikian, siswa kelas delapan dianggap sesuai untuk penelitian ini.

Dari empat kelas pada kelas delapan, dipilih secara random tiga kelas yang menjadi tempat kajian dan terpilih kelas delapan C (32 siswa) sebagai tempat uji coba, dan kelas delapan B (34 siswa) dan D (33 siswa) sebagai kelas untuk melaksanakan implementasi model. Sebelum dilakukan kajian uji coba dan implementasi model PMBP, telah dihitung nilai rata-rata dan kesamaan kemampuan awal ketiga kelas tersebut dengan uji analis anova satu jalan (one way anova), serta telah dilakukan pemenuhan persyaratan yang harus dipenuhi sebelum uji anova satu jalan yaitu: (a) kenormalan data; dan (b) kesamaan varian (Santoso, 2009; Sugiyono, 2011; Sukmadinata, 2012). Data kemampuan awal ketiga kelas yang digunakan diperoleh dari hasil ujian pada semester sebelumnya yang dimiliki guru.

Dalam penelitian ini pengumpulan datanya menggunakan teknik angket, observasi, dan tes.Sebelum instrumen digunakan untuk memperolehi data, instrumen tersebut telah dinilai kevalidan dan reliabelitasnya. Hal ini dilakukan untuk memperoleh instrumen yang baik atau berkualitas.

Teknik analisis data yang digunakan yaitu teknis analisis data secara kualitatif dan secara kuantitatif. Dalam penelitian ini metode penelitian kualitatif dan kuantitatif digunakan saling melengkapi (Creswell, 2009). Teknik analisis kualitatif dengan menggunakan model analisis interaktif (Sugiyono, 2011; Miles \& Hubermen, 1986), yaitu reduksi data (data reduction), sajian data (data display), dan penarikan kesimpulan/verifikasi (conclusion drawing/ verification).Data kuantitatif dianalisis secara kuantitatif dengan teknik analisis statistik deskriptif (rata-rata, prosentase), uji kenormalan data, uji kesamaan varian, uji analis anova satu jalan (one way anova) dan uji t.

Untuk menilai model PMBP, dilakukan penilaian kevalidan, kepraktisan dan keefektifan model (produk). Kriteria kevalidan model ditentukan oleh 5 ahli dan 2 praktisi 
(guru) dan instrumen untuk mengukur kevalidan adalah lembar kevalidan. Hasil penilaian ahli dan guru dikatakan memenuhi kevalidan jika termasuk dalam kategori "valid". Kriteria model ini dikatakan praktis jika para ahli atau praktisi (guru) menyatakan bahwa model dapat diterapkan di sekolah dan peringkat keterlaksanaannya model termasuk kategori "baik". Instrumen untuk mengukur kepraktisan adalah lembar observasi. Kriteria model dikatakan efektif dilihat dari: (1) hasil belajar siswa menunjukkan hasil belajar yang baik; (2) aktivitas siswa menunjukkan hasil yang baik; dan (3) respon siswa terhadap pelaksanaan pembelajaran adalah baik. Instrumen untuk mengukur keefektifan model adalah intrumen ujian hasil belajar, lembar pengamatan aktivitas siswa, dan angket respon siswa terhadap pembelajaran.

Setelah model PMBP berhasil dikembangkan dan diujicobakan serta dinilai sehingga menjadi produk yang valid, praktis dan efektif, maka produk model PMBP perlu diimplementasikan untuk wilayah yang lebih luas untuk penelitian lanjutan (Plomp, 1997; Rochmad, 2012; Gall \& Borg, 2003; Sukmadinata (2012). Dalam implementasi, dapat dilakukan melalui sekolah yang sama dan guru yang sama dalam kelas yang berbeda (Sukmadinata, 2012). Implementasi model PMBP dilakukan dengan desain eksperimen.

\section{HASIL DAN PEMBAHASAN}

\section{Hasil Isvestigasi Awal atau Kajian Awal}

Investigasi awal atau kajian awal dilakukan untuk mengkaji dan menganalisis keadaan yang terkait dengan pembelajaran matematika di sekolah dan teori-teori yang terkait dengan pelaksanaannya, yang meliputi: kurikulum matematika yang dijalankan, model pembelajaran yang dijalankan, komponen pembelajaran yang digunakan, keadaan siswa di sekolah tempat kajian, identifikasi kebutuhan siswa dan guru dalam pelaksanaan model pembelajaran, dan melakukan pengkajian terhadap teori-teori dan model pembelajaran yang mendukung pengembangan model yang terkait dengan masalah yang ditemukan dalam investigasi awal.

1) Pada waktu penelitian dilaksanakan, kurikulum yang dilaksanakan di Indonesia adalah kurikulm 2006 dan kurikulum 2013. Untuk satuan pendidikan yang belum siap melaksanakan kurikulum 2013, diijinkankan melaksanakan kurikulum 2006. Di sekolah tempat kajian ini, melaksanakan kurikulum 2013 karena ketentuan dari Kantor Pendidikan Kota Malang yang mewajibkan semua sekolah untuk melaksanakan kurikulum 2013. Jumlah jam pelajaran matematika di SMP adalah 5 jam pelajaran setiap minggu.

Kurikulum pada dasarnya adalah sebuah perencanaan atau program pengalaman siswa yang diarahkan sekolah (Sanjaya, 2006). Kurikulum sebagai perangkat rencana dan pengaturan mengenai tujuan, isi, dan materi pelajaran serta cara yang digunakan sebagai pedoman penyelenggaraan aktivitas pembelajaran untuk mencapai tujuan pendidikan tertentu (Depdiknas, 2003). Oleh karena itu, kurikulum memiliki implikasi terhadap pelaksanaan pembelajaran di kelas. Dalam pelaksanaan pembelajaran memerlukan model pembelajaran, karena model pembelajaran dapat membantu siswa untuk mencapai tujuan pembelajaran 
(Eggen \& Kauchack, 2012; Rusman, 2012). Hal ini juga didukung pendapat Joyce dan Weil (2009) bahwa model pembelajaran merupakan rancangan yang dapat digunakan untuk merancang kurikulum dan mengarahkan aktivitas pembelajaran.

2) Hasil kajian tentang model pembelajaran yang dijalankan di sekolah kajian ini menunjukkan bahwa pengajaran pembelajaran seperti yang diharapkan kurikulum 2013 belum dapat terlaksana dengan baik. Guru masih sering menggunakan model yang konvensional, pembelajaran matematika yang dijalankan guru masih sering berpusat kepada guru, belum banyak melibatkan siswa secara aktif.

Dalam implementasi kurikulum 2013 ditekankan bahwa dalam pembelajaran disarankan menggunakan prinsip diantaranya tidak lagi menggunakan pendekatan tekstual tetapi pendekatan ilmiah atau saintifik (scientific). Untuk memperkuat pendekatan saintifik perlu model-model pembelajaran yang mendorong kemampuan siswa untuk menghasilkan karya kontekstual baik ecara individual maupun kelompok yang melibatkan siswa secara aktif (Kemendikbud, 2013a). Walaupun sudah ada ketentuan dalam implementasi kurikulum 2013 bahwa guru diharapkan menggunakan model atau pendekatan yang melibatkan siswa aktif secara maksimal (Kemendikbud, 2013a; Kemendikbud, 2013b), tetapi guru masih sering menggunakan metode konvensional yang berpusat pada guru. Pandangan guru tentang model pembelajaran perlu diubah pada pandangan pembelajaran yang berpusat kepada siswa, yang mengaktifkan siswa. Hal ini sesuai dengan pendapat Walle (2012), Jacobsen dkk (2009), NCTM (2000), dan Turmudi (2009b) bahwa dalam pembelajaran matematika, siswa harus aktif mengontruksi pemahaman matematika.

3) Hasil kajian tentang komponen pembelajaran yang digunakan guru menunjukkan bahwa guru di tempat kajian ini belum memiliki keterampilan yang baik dalam membuat Rencana Pengajaran dan pembelajaran (RPP) yang betul-betul sesuai kurikulum 2013. Guru membuat RPP sekedar dapat membuat sesuai pengetahuan yang dimilikinya. Guru masih belum faham betul dengan pelaksanaan kurikulum 2013. Guru di sekolah tempat kajian ini menggunakan Lembar Kerja Siswa (LKS) yang lama artinya LKS yang lama (2006), sedangkan kurikulum yang dilaksanakan di sekolah ini adalah kurikulum baru (2013) dan penggunaan LKS ini jarang dilakukan oleh guru tersebut karena guru tidak membuat LKS sendiri.

Di dalam proses pembelajaran menurut kurikulum 2013, guru diharuskan menggunakan sumber belajar berupa buku teks dan juga sumber belajar selain buku teks (Kemendikbud, 2013b). Sumber selain buku teks dapat berbentuk seperti LKS. Guru perlu membuat perangkat pembelajaran (buku siswa, RPP dan LKS) sesuai dengan kurikulum yang dijalankan, karena perangkat pembelajaran berfungsi sebagai pedoman dalam menyelenggarakan pembelajaran yang sistematik dan berfungsi sebagai pedoman dalam mencapai tujuan pembelajaran (Sanjaya, 2008). Hal ini didukung oleh pendapat Joyce dan Weil (2009) bahwa perangkat pembelajaran sangat penting karena perangkat pembelajaran (sistem pendukung) sangat diperlukan dalam implementasi model pembelajaran. 
4) Hasil kajian tentang keadaan siswa menunjukkan bahwa hasil belajar matematika dari siswa masuk dalam kategori kurang. Mayoritas siswanya adalah siswa yang tidak diterima masuk sekolah negeri atau tidak diterima masuk sekolah favorit peringkat tinggi. Oleh karena itu guru harus berusaha memotivasi dan mendorong siswa untuk meningkatkan prestasi belajar matematikanya baik secara psikologis mahupun secara pedagogis, karena guru memiliki peranan penting dalam meningkatkan hasil belajar siswa (Slameto, 2010; Sanjaya 2008).

5) Hasil kajian tentang hasil identifikasi kebutuhan siswa dan guru diperoleh informasi bahwa mayoritas siswa merasa senang jika dalam pembelajaran matematika melaksanakan model pembelajaran berbasis portofolio yaitu model pembelajaran yang memberikan pengalaman-pengalaman belajar siswa melalui suatu rangkaian tugas matematika yang membahas suatu masalah (soal) yang dapat menghasilkan pengetahuan (kognitif), keterampilan (skill), dan sikap (afektif). Hal ini menunjukkan bahwa siswa memerlukan model pembelajaran matematika yang dapat mengaktifkan siswa dalam aktivitas pembelajaran yaitu model PMBP. Sedangkan hasil angket yang diberikan kepada guru berkaitan dengan kebutuhan guru terhadap model pembelajaran, guru menyatakan setuju atau mendukung jika dikembangkan model PMBP. Dari hasil ini menunjukkan bahwa sebenarnya guru memerlukan model pembelajaran yang dapat meningkatkan kualitas pembelajaran matematika.

Kebutuhan (needs) adalah kesenjangan (gap) antara apa yang diharapkan dengan kondisi yang sebenarnya (Sanjaya, 2008). Identifikasi kebutuhan dapat digunakan sebagai alat untuk mengidentifikasi masalah guna menentukan tindakan yang tepat. Identifikasi kebutuhan dapat digunakan untuk mengumpulkan data dalam investigasi awal (Plomp, 1997). Dalam kajian ini, identifikasi kebutuhan dilakukan untuk melengkapi informasi dari guru dan siswa tentang pelaksanaan model pembelajaran di sekolah selama ini, apakah ada masalah, apa penyebabnya, apakah model pembelajaran yang digunakan guru selama ini sudah sesuai, dan apakah jalan keluar penggunaan model PMBP merupakan sesuatu yang diperlukan siswa dan guru dan sebagainya.

6) Berdasarkan telaah atau kajian pustaka tentang teori-teori yang berkaitan model pembelajaran yang mendukung pengembangan model diperoleh informasi bahwa teori-teori pembelajaran yang dipandang dapat digunakan untuk landasan penyelesaian masalah pembelajaran dari hasil kajian sebelumnya yaitu teori pembelajaran konstruktivistik yang dikembangkan oleh Peaget dan Vygotsky, teori Dewey, teori Bruner, teori Ausubel, teori Gagne dan teori penelitian pengembangan model Plomp.

Teori-teori pembelajaran diperlukan dalam memperoleh model pembelajaran yang berkualitas. Hal ini sesuai dengan pendapat Hudoyo (2005) dan Muhsetyo (2008) bahwa untuk memperoleh pembelajaran yang berkualitas baik, perlu melaksanakan pembelajaran sesuai dengan teori-teori pembelajaran.

Berdasarkan hasil investigasi awal atau kajian awal maka salah satu alternatif model pembelajaran yang diharapkan dapat digunakan untuk mengatasi masalah pembelajaran yang 
terjadi dan sesuai dengan teori-teori pembelajaran adalah model pembelajaran matematika berbasis portofolio (PMBP).

\section{Hasil Rancangan (Design) Model PMBP}

Berdasarkan hasil kajian awal, maka disusun rancangan model PMBP. Rancangan model dalam kajian ini meliputi: (1) rancangan buku model; (2) rancangan komponen pembelajaran (buku siswa, RPP, LKS); dan (3) rancangan instrumen untuk memperoleh data dalam proses pengembangan model.

Rancangan buku model meliputi uraian tentang: (1) rasional model PMBP; (2) teoriteori pendukung; (3) komponen-komponen model; dan (4) petunjuk pelaksanaan model. Rancangan komponen model pembelajaran mencakup: (a) buku siswa; (b) rencana pengajaran dan pembelajaran (RPP); dan (c) lembar kerja siswa (LKS). RPP dirancang dengan mempertimbangkan beberapa hal yaitu: (a) menekankan terciptanya pengertian (meaning), bukan hafalan tanpa pengertian, dan (b) mengusahakan keadaan yang memungkinkan siswa mengkonstruksi pengetahuannya baik secara individu maupun secara kelompok dengan menerapkan model PMBP. LKS dirancang dengan mempertimbangkan beberapa hal, yaitu: (1) memungkinkan siswa mencapai kompetensi sesuai indikator atau tujuan pembelajaran yang ditetapkan; (2) memungkinkan siswa mengkonstruksi pengetahuannya; dan (3) menyokong munculnya curah pendapat (sumbang saran). Rancangan instrumen mencakup instrumen untuk menilai: (1) kevalidan; (2) kepraktisan; dan (3) keefektifan model.

\section{Hasil Realisasi/konstruksi (Realization/Construction) Model PMBP.}

Hasil dari rancangan model selanjutnya diuraikan lagi secara mendetail sehingga menjadi realisasi/konstruksi model atau prototype awal. Realisasi /konstruksi model merupakan hasil dari pengembangan model sebelum dijalankan pengujian kevalidan model. Hasil realisasi/konstruksi model ini meliputi draft: (1) buku model; (2) buku siswa; (3) LKS; (4) RPP; dan (5) instrumen penilaian model.

Buku model adalah model pembelajaran yang berhasil dikembangkan yang dikemas dalam bentuk buku. Buku model yang direalisasikan dalam pengembangan model ini terdiri dari tiga bab. Pada bab 1 diuraikan mengenai landasan teoritis model PMBP yang meliputi: (1) latar belakang; (2) model pembelajaran; (3) pendekatan pembelajaran; (4) strategi pembelajaran; (5) metode pembelajaran; (6) teori Piaget; dan (7) teori Vygotsky, (8) teori Dewey; (9) teori Bruner; (10) teori Ausubel; dan (11) teori Gagne. Hubungan model, pendekatan, strategi dan metode terlihat pada Gambar 2. Pada bab 2 diuraikan mengenai model PMBP yang meliputi: (1) kajian model PMBP; (2) prinsip dasar model PMBP; dan (3) komponen-komponen model PMBP yang meliputi sintaks, sistem sosial, prinsip reaksi, sistem pendukung, dan dampak instruksional dan dampak pengiring (uraian kelima komponen model PMBP secara ringkas dapat dilihat dalam Gambar 1). Pada bab 3 diuraikan mengenai petunjuk pelaksanaan pembelajaran model PMBP yang meliputi: (1) penyusunan perancangan tujuan pembelajaran; (2) pelaksanaan pembelajaran; (3) pengorganisasian kelas; 
(4) penilaian; (5) penyusunan perangkat pembelajaran (RPP dan LKS) serta dilengkapi contoh RPP dan LKS.

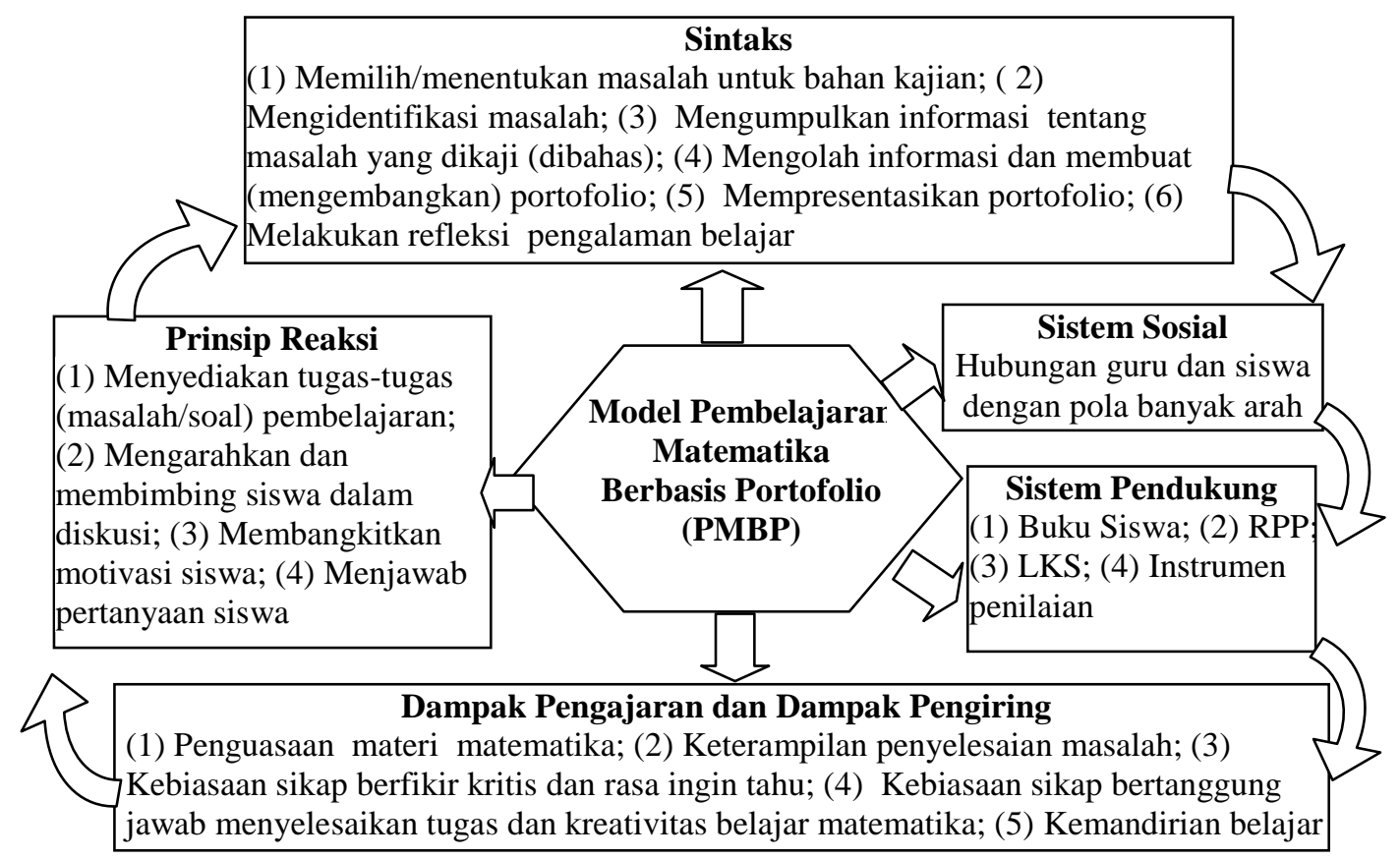

Gambar 1: Model Pembelajaran Matematika Berbasis Portofolio (PMBP)

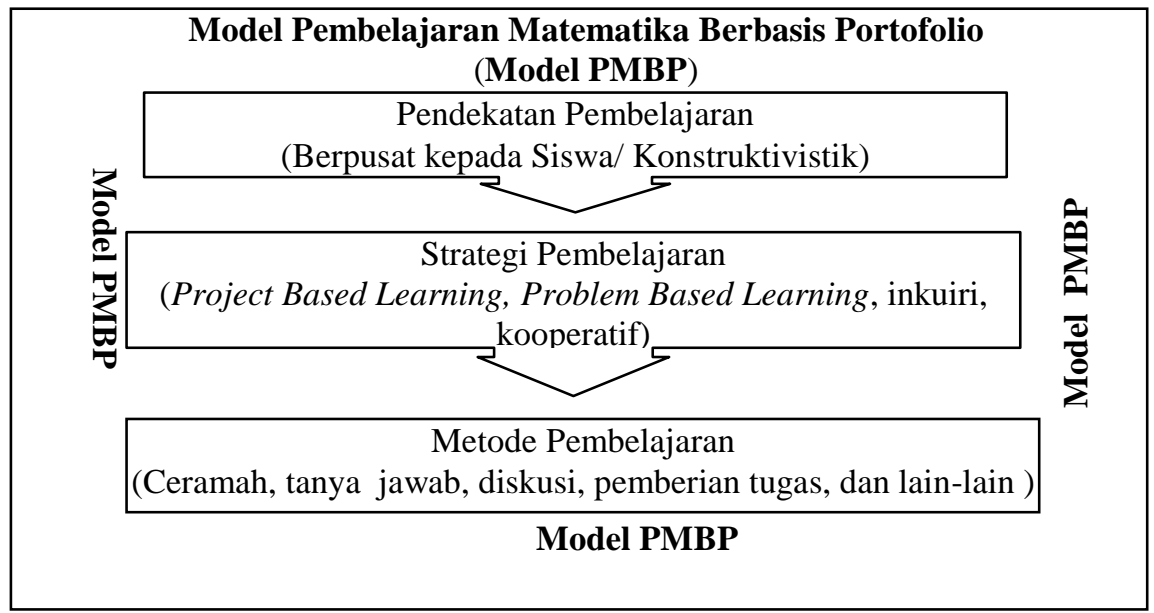

Gambar 2: Hubungan antara Model, Pendekatan, Strategi dan Metode

Hubungan antara model pembelajaran, pendekatan, strategi dan metode pembelajaran sangat berkaitan. Model pembelajaran memiliki cakupan lebih luas dari pendekatan, strategi, dan metode karena untuk menyusun sebuah model pembelajaran harus menentukan pendekatan, strategi, dan metode yang akan digunakan. Strategi pembelajaran yang dijalankan guru tergantung pada pendekatan yang digunakan. Strategi pembelajaran merupakan implementasi dari model dan pendekatan pembelajaran. Dalam menjalankan strategi itu dapat dilaksanakan berbagai metode pembelajaran. Jika antara pendekatan, strategi dan metode sudah terangkai menjadi satu kesatuan yang utuh maka terbentuklah yang 
disebut model pembelajaran. Jadi model pembelajaran, pada umumnya merupakan bentuk pembelajaran yang tergambarkan dari awal sampai akhir yang dilaksanakan secara khusus oleh guru. Dengan kata lain, model pembelajaran merupakan bungkus atau bingkai dari penerapan suatu pendekatan, strategi dan metode

RPP adalah rencana aktivitas pembelajaran untuk satu pertemuan atau lebih yang digunakan untuk mengarahkan aktivitas pembelajaran siswa dalam usaha mencapai Kompetensi Dasar (KD). RPP memuat diantaranya kompetensi inti, kompetensi dasar, indikator, tujuan pembelajaran, materi, model/pendekatan/strategi/metode, tahapan aktivitas pembelajaran, dan penilaian. Realisasi/konstruksi RPP dibuat 6 pertemuan sesuai topik yang telah ditentukan.

Realisasi/konstruksi LKS didasarkan pada kompetensi dasar yang ada pada RPP. Dari kompetensi dasar kemudian diuraikan ke dalam indikator. Selanjutnya menyusun dan mengorganisasikan tugas-tugas dan soal-soal atau masalah yang sesuai dengan indikator pencapaian kompetensi yang ditetapkan dan peruntukan waktu yang tersedia serta kemampuan rata-rata siswa. Realisasi/konstruksi LKS dibuat 6 pertemuan sesuai topik yang telah ditentukan dan sesuai RPP.

Hasil dari realisasi/konstruksi instrumen penelitian dalam pengembangan model PMBP ini digunakan untuk menilai kevalidan komponen model (instrumen kevalidan buku model, buku siswa, LKS, dan RPP), kepraktisan model (instrumen pelaksanaan pembelajaran, serta keterlaksanaan model), keefektifan model (instrumen penilaian hasil belajar, aktivitas siswa, respon siswa) dan menilai hasil implementasi model. Sebelum digunakan untuk menilai kevalidan, kepraktisan dan keefektifan model PMBP ini, instrumeninstrumen tersebut juga diuji dan telah memenuhi validitas dan reliabelitas instrumen.

\section{Hasil Uji Validasi Ahli, Uji Coba (Uji Kepraktisan dan Uji Keefektifan) Model}

1) Uji Validasi Ahli

Penilaian kevalidan model dan komponen-komponen model (buku siswa, RPP, LKS) dilakukan oleh tujuh ahli yang teridiri dari lima dosen pendidikan matematika dan dua guru matematika, yang secara ringkas dapat ditunjukkan pada tabel berikut.

\section{Tabel 1: Hasil Validasi Ahli terhadap Model dan Komponen-komponen Model}

\begin{tabular}{lll}
\hline No & Item yang Dinilai & Hasil Rata-rata \\
\hline 1. & Penilaian Buku Model & 3.59 \\
2. & Penilaian Buku Siswa & 3.61 \\
3. & Penilaian RPP & 3.72 \\
4. & Penilaian LKS & 3.55 \\
\hline
\end{tabular}

Berdasarkan tabel di atas, penilaian kevalidan oleh para ahli diperoleh hasil penilaian buku model sebesar 3.59, buku siswa sebesar 3.61, RPP sebesar 3.72 dan LKS sebesar 3.55 dan berdasarkan kriteria kevalidan model yang ditetapkan yaitu lebih besar dari 3 sehingga dapat dikatakan bahwa model dan komponen-komponen yang dikembangkan masuk dalam kategori valid. Selain memberikan penilaian kevalidan model dan komponen-komponen model, para ahli juga memberikan masukan untuk perbaikan (revisi) model dan komponen- 
komponennya. Untuk menyempurnakan model dan komponen-komponennya telah dilakukan perbaikan (revisi) sesuai dengan masukan dan saran dari para ahli.

2) Uji Kepraktisan Model

Setelah berhasil melakukan penilaian kevalidan model dan komponen-komponennya dan revisi model, kemudian dilakukan uji coba model dan komponen-komponennya untuk mendapatkan hasil kepraktisan dan keefektifan model PMBP. Untuk mengetahui kepraktisan model, dilakukan dengan melakukan pemerhatian dengan menggunakan instrumen penilaian pelaksanaan pembelajaran dan instrumen penilaian keterlaksanaan model yang dilakukan oleh dua orang pemerhati, yang secara ringkas dapat ditunjukkan pada tabel berikut.

\section{Tabel 2: Hasil Penilaian Pelaksanaan dan Keterlaksanaan Model PMBP}

\begin{tabular}{lll}
\hline No & Item yang Dinilai & Hasil Rata-rata \\
\hline 1. & Pelaksanaan Pembelajaran & 3.22 \\
2. & Keterlaksanaan Pembelajaran & 3.19 \\
\hline
\end{tabular}

Hasil penilaian pelaksanaan pembelajaran diperolehi rata-rata 3.22 dan berdasarkan kriteria yang ditetapkan maka masuk dalam kategori tinggi. Sedangkan hasil penilaian keterlaksanaan model diperoleh rata-rata 3.19 dan berdasarkan kriteria yang telah ditetapkan maka berada dalam kategori terlaksana seluruhnya. Dari hasil penilaian ini menunjukkan bahwa penilaian kepraktisan model PMBP telah memenuhi kriteria model yang praktis.

3) Uji Keefektifan Model

Penilaian keefektifan model didasarkan pada hasil analisis tiga aspek yaitu: (1) hasil belajar; (2) aktivitas siswa; dan (3) respon siswa terhadap pembelajaran yang melaksanakan model PMBP. Penilaian hasil belajar siswa dapat dilihat pada tabel berikut.

\section{Tabel 3: Penilaian Hasil Siswa}

\begin{tabular}{llll}
\hline No. & Hasil Belajar $(\mathrm{X})$ & Frekuensi $(\%)$ & Kriteria \\
\hline 1. & $\mathrm{X} \geq 65$ & 25 siswa $(78.13 \%)$ & Berhasil \\
2. & $\mathrm{X}<65$ & 7 siswa $(21.88 \%)$ & Tidak Berhasil
\end{tabular}

Berdasarkan tabel dia atas, hasil belajar diperoleh bahwa siswa yang memperoleh skor lebih dari atau sama dengan 65 (berhasil) sebanyak 25 siswa atau 78.13\%. Hal ini menunjukkan bahwa hasil belajar siswa telah memenuhi kriteria yang ditetapkan yaitu kriteria keberhasilan klasikal yang didasarkan kepada pencapaian minimum $75 \%$ dari siswa mencapai skor minimum 65 sudah terpenuhi.

Hasil observasi terhadap aktivitas sebagai mana tabel berikut.

Tabel 4: Prosentase Aktivitas Siswa

\begin{tabular}{|c|c|c|}
\hline Jenis Aktivitas Siswa & Rata-rata & Kriteria \\
\hline (1) Mendengarkan dan memperhatikan penjelasan guru & $12.79 \%$ & $7.5 \%-15 \%$ \\
\hline $\begin{array}{l}\text { (2) Membaca Buku/LKS, mengerjakan soal/LKS } \\
\text { secara individu }\end{array}$ & 12. & $7.5 \%-15 \%$ \\
\hline (3) Terlibat diskusi secara kelompok & $12.11 \%$ & $7.5 \%-15 \%$ \\
\hline $\begin{array}{l}\text { (4) Bekerja secara kelompok untuk membuat } \\
\text { portofolio atau menyelesaikan soal tugas }\end{array}$ & $11.69 \%$ & $7.5 \%-15 \%$ \\
\hline
\end{tabular}


(5) Menyampaikan pertanyaan, idea atau meminta $11.04 \% \quad 7.5 \%-15 \%$ penjelasan kepada rekan atau guru

(6) Memberikan respon kepada guru atau memberikan $10.18 \% \quad 7.5 \%-15 \%$ bantuan kepada rekan

(7) Memperbaiki hasil kerja atau menuliskan suatu $5.10 \% \quad 3 \%-7 \%$ yang baru dari hasil diskusi

(8) Mempresentasikan portofolio hasil diskusi di kelas $\quad 0.60 \% \quad 0-3 \%$ atau mengerjakan soal di depan kelas

Dari tabel di atas diperoleh informasi bahwa semua jenis aktivitas siswa telah memenuhi kriteria yang telah ditetapkan. Dengan demikian dapat dikatakan bahwa aktivitas siswa telah memenuhi salah satu syarat keefektifan model.

Hasil dari analisis respon siswa terhadap pembelajaran dengan model PMBP dapat diperoleh informasi sebagai mana tabel berikut.

Tabel 5: Distribusi Frekuensi Respon Siswa terhadap Pembelajaran

\begin{tabular}{lll}
\hline No & Indikator & Skor Rata-rata \\
\hline 1 & Ketertarikan & 3.47 \\
2 & Kemutakhiran & 3.31 \\
3 & Tingkat Kemudahan & 3.41 \\
\hline Rata-rata Keseluruhan & 3.40
\end{tabular}

Dari tabel di atas hasil respon siswa pada segi ketertarikan sebesar 3.47, pada segi kemutakhiran sebesar 3.31 dan pada tingkat kemudahan sebesar 3.41. Hasil respon siswa diperoleh rata-rata respon siswa secara keseluruhan sebesar 3.40 dan sesuai dengan kriteria yang telah ditetapkan, hal ini termasuk dalam kategori tinggi. Ini berarti siswa secara umum tidak mengalami kesukaran dalam mengikuti aktivitas pembelajaran dengan model PMBP.

Dari hasil ketiga aspek prestasi belajar, aktivitas siswa dan respon siswa maka penilaian keefektifan model telah memenuhi kriteria model pembelajaran yang efektif.

\section{Hasil Implementasi Model}

Implementasi model PMBP dilakukan dengan desain eksperimen "desain kelompok pembanding pretest-posttest berascak" (the randomized pretest-posttest comparison group design). Dalam pelaksanaannya dilakukan pencarian perbedaan: (1) kemampuan awal (pretest) dua kelompok eksperimen dan kelompok kontrol (uji t); dan (2) kemampuan posttest kelompok eksperimen dan kontrol (uji t). Sebelum dilakukan uji t, data telah dianalis sehingga memenuhi syarat kenormalan data dan kesamaan varian (Santoso, 2009; Sugiyono, 2011; Sukmadinata, 2012). Kenormalan data dilakukan dengan menggunakan P-P Plot SPSS 19.0, yang ditunjukkan grafik (plot) dengan titik-titik menyebar di sekitar garis diagonal dan sebarannya mengikuti arah garis diagonal, yang berarti data tersebut berdistribusi normal (Santoso, 2009).

Kelas delapan B dan D adalah kelas delapan yang memiliki kemampuan yang sama (homogin). Setelah dilakukan pemilihan kelas secara random, maka kelas delapan D terpilih sebagai kelompok eksperimen dan kelas delapan B sebagai kelompok kontrol. 
1) Uji Perbedaan Rata-rata Hasil Pretest Kelompok Eksperimen dan Kontrol

Untuk menguji perbedaan rata-rata dengan jumlah subyek siswa tidak sama $\left(\mathrm{n}_{1} \neq \mathrm{n}_{2}\right)$ dan varian homogin maka menggunakan uji t ( $t$ test) dengan pooled varian (Sugiyono, 2013). Untuk menganalis data dilakukan dengan program SPSS 19.0.

Penilaian perbedaan rata-rata dengan menggunakan analisis uji t dilakukan dengan program SPSS 19.0 yang ditunjukkan sebagaimana tabel berikut:

\section{Tabel 6: Data Hasil Pretest Kelompok Eksperimen dan Kelompok Kontrol}

\begin{tabular}{lllll}
\hline Group Statistics & & & & \\
\hline & Nama Kelompok & N & Mean & $\begin{array}{l}\text { Std. } \\
\text { Deviation }\end{array}$ \\
\hline \multirow{2}{*}{ NILAI PRETEST } & Kelompok Kontrol & 34 & 62.94 & 6.41 \\
\cline { 2 - 5 } & Kelompok Eksperimen & 33 & 63.18 & 7.89 \\
\hline
\end{tabular}

Independent Samples Test

\begin{tabular}{llllll}
\hline \multicolumn{2}{l}{ Levene's Test for Equality of Variances } & \multicolumn{2}{l}{$\begin{array}{l}\text { t-test for } \\
\text { Means }\end{array}$} & Equality of \\
\hline F & Sig. & t & df & Sig. (2-tailed) \\
\hline 2.523 & 0.118 & -0.137 & 65 & 0.891 \\
\hline
\end{tabular}

Dari diatas, rata-rata kelompok kontrol adalah 62.94 dan rata-rata kelompok eksperimen adalah 63.18. Nilai $\mathrm{F}=2.523$ dengan tingkat signifikansi 0.118 dan nilai ini lebih besar dari 0.05 yang berarti varian kedua nilai test adalah homogin (sama). Nilai $\mathrm{t}=-0.137$ dengan tingkat signifikansi 0.891 dan nilai ini lebih besar dari 0.05 yang berarti $\mathrm{H}_{\mathrm{o}}$ (tidak terdapat perbedaan rata-rata pretest kelompok kontrol dan kelompok eksperimen) adalah diterima, jadi kedua kelompok kelas sebagai subyek sebelum dilakukan kajian eksperimen adalah memiliki kemampuan awal yang sama.

2) Uji Perbedaan Rata-rata Hasil Posttest Kelompok Eksperimen dan Kontrol

Untuk menguji perbedaan rata-rata dengan jumlah subyek siswa tidak sama $\left(\mathrm{n}_{1} \neq \mathrm{n}_{2}\right)$ dan varian homogin $\left(\sigma_{1}{ }^{2}=\sigma_{2}{ }^{2}\right)$ maka menggunakan uji $\mathrm{t}(t$ test $)$ dengan pooled varian (Sugiyono, 2013). Dengan program SPSS 19.00 diperoleh hasil sebagaimana tabel berikut:

Tabel 7: Data Hasil Posttest Kelompok Eksperimen dan Kelompok Kontrol

\begin{tabular}{llllll}
\hline \multicolumn{1}{l}{ Group Statistics } & & & \\
\hline & Nama Kelompok & & $\mathrm{N}$ & Mean & $\begin{array}{l}\text { Std. } \\
\text { Deviation }\end{array}$ \\
\cline { 2 - 3 } \cline { 5 - 6 } NILAI & & 34 & 67.65 & 5.93 \\
POSTTEST & Kelompok Kontrol & & 33 & 72.58 & 7.92 \\
\hline
\end{tabular}

Independent Samples Test 


\begin{tabular}{|c|c|c|c|c|}
\hline \multicolumn{2}{|c|}{ Levene's Test for Equality of Variances } & \multicolumn{3}{|c|}{ t-test for Equality of Means } \\
\hline $\mathrm{F}$ & Sig. & $\mathrm{t}$ & df & $\begin{array}{l}\text { Sig. } \\
\text { tailed })\end{array}$ \\
\hline 3.175 & 0.079 & -2.889 & 65 & 0.005 \\
\hline
\end{tabular}

Dari tabel di atas diperoleh informasi bahwa rata-rata posttest kelompok kontrol adalah 67.65 dan rata-rata posttest kelompok eksperimen adalah 72.58. Nilai $F=3.175$ dengan tingkat signifikansi 0.079 dan nilai ini lebih besar dari 0.05 yang berarti varian kedua-dua nilai tes adalah homogin (sama). Sedangkan nilai $\mathrm{t}=-2.889$ dengan tingkat signifikansi 0.005 dan nilai ini lebih kecil dari 0.05 yang berarti $\mathrm{H}_{\mathrm{o}}$ (tidak terdapat perbedaan rata-rata posttest kelompok kontrol dan kelompok eksperimen) adalah tidak diterima. Hal ini menunjukkan bahwa kedua kelompok kelas sebagai subyek setelah dilakukan kajian eksperimen adalah memiliki kemampuan yang berbeda dan nilai rata-rata posttest kelompok eksperimen lebih besar dari nilai rata-rata posttest kelompok kontrol. Hal ini menujukkan bahwa kelompok ekperimen (model PMBP) lebih efektif dari pada kelompok kontrol (model konvensional).

Secara umum, hasil dari uji eksperimentasi menunjukkan bahwa model PMBP berpengaruh baik terhadap prestasi belajar matematika. Hasil kajian ini dapat digunakan mendukung dan mengembangkan teori pembelajaran khususnya pembelajaran matematika. Selama ini, banyak guru melaksanakan pembelajaran dengan teori pembelajaran konvensional, yang kurang mengaktifkan siswa dalam proses pembelajaran matematika serta hasil pembelajaran yang diperoleh kurang baik (Hudoyo, 2005; Marpaung, 2003; Pambudi, 2007; Trianto, 2011; Suyono 2012). Model PMBP merupakan inovasi pembelajaran yang didasarkan pada teori-teori pembelajaran yaitu teori pembelajaran konstruktivistik Piaget dan Vygotsky, terori Dewey, teori Bruner, teori Ausubel, dan teori Gagne. Model PMBP adalah model pembelajaran inovatif yang menerapkan prinsip-prinsip pembelajaran yang dapat: mengaktifkan siswa, dapat memotivasi siswa untuk berpartisipasi aktif, memberikan tempat yang cukup untuk inisiatif siswa, mengembangkan kreativitas dan kemandirian belajar, menciptakan kondisi menyenangkan dan menantang, serta menyediakan pengalaman belajar yang beragam, kontekstual, dan bermakna.

Guru memiliki peran sebagai perencana (planner) dan perancang (designer) dalam pembelajaran (Sanjaya, 2006; Mulyasa, 2013). Guru dalam merancang pembelajaran yang efisiensi dan efektif di sekolah memerlukan model pembelajaran serta dasar-dasar teori pembelajaran (Hudoyo, 2005; Muhsetyo, 2008). Untuk itu, guru dalam merencanakan dan merancang pembelajaran memerlukan teori-teori dan model-model pembelajaran yang dapat membawa dampak pembelajaran yang efektif dan efesiensi. Hasil penelitian pengembangan model PMBP ini dapat memberikan kefahaman bahwa dalam pembelajaran matematika terdapat landasan yang dapat digunakan untuk meningkatkan profesionalisme guru dalam melaksanakan pembelajaran matematika. Hasil penelitian pengembangan PMBP ini dapat digunakan sebagai dasar dalam merancang aktivitas pembelajaran matematika yang efektif 
dan efisien karena telah terbukti bahwa model PMBP memberikan dampak efektif terhadap hasil belajar matematika.

Hasil penelitian ini dapat menambah khazanah teori pembelajaran. Model pembelajaran matematika berbasis portofolio (PMBP) penting dijalankan sebagai alternatif model pembelajaran dalam meningkatkan keberhasilan belajar matematika siswa. Hal ini sesuai pernyataan Rizali dkk (2009) yang menyatakan bahwa guru harus selalu aktif mengikuti perkembangan model, pendekatan, strategi dan metode pembelajaran melalui aktivitas-aktivitas kelompok profesi, melalui jurnal-jurnal, mahupun hasil-hasil penelitian.

\section{KESIMPULAN}

Penelitian pengembangan model pembelajaran matematika berbasis portofolio (PMBP) ini mengikuti tahap-tahap pengembangan model yang diadaptasi dari Plomp (1997), dengan tahap: (1) investigasi awal (preliminary investigation) atau kajian awal, (2) perancangan (design); (3) realisasi/konstruksi (realization/construction); (4) uji kevalidan, uji coba (kepraktisan dan keefektifan), dan revisi; dan (5) implementasi (implemenatation). Kualitas hasil dari model yang dikembangkan, dinilai dengan menggunakan kriteria Nieveen (1999) yaitu valid, praktis dan efektif. Komponen-komponen dari model PMBP yang dikembangkan mengikuti konsep Joyce dan Weil (2009) yang terdiri dari lima komponen, yaitu sintaks, sistem sosial, prinsip reaksi, sistem pendukung, dan dampak instruksional dan pengiring.

Hasil investigasi awal atau kajian awal menunjukkan: (a) sekolah tempat kajian mengimplemetasikan kurikulum 2013, tetapi guru masih belum faham betul dengan implementasi kurikulum 2013 yang akibatnya guru masih sering menggunakan model pembelajaran yang konvensional; (b) Guru jarang menggunakan LKS dan jika menggunakan LKS maka LKS yang masih beracuan kurikulum 2006. Guru membuat RPP sekedar dapat membuat sesuai pengetahuan yang dimilikinya; (c) Hasil belajar matematika siswa masuk dalam kategori kurang; (d) Hasil identifikasi kebutuhan siswa menunjukkan bahwa mayoritias siswa merasa senang jika dalam pembelajaran matematika menerapkan model PMBP. Guru juga menyatakan mendukung jika dikembangkan model PMBP; (e) Teori-teori yang mendasari pengembangan model PMBP adalah teori pembelajaran konstruktivistik Piaget dan Vygotsky, terori Dewey, Bruner, Ausubel, Gagne, dan teori pengembangan produk model dari Plomp.

Hasil rancangan (desain) model PMBP meliputi: (1) rancangan buku model; (2) rancangan komponen model pembelajaran (buku siswa, RPP, LKS); dan (3) rancangan instrumen yang digunakan untuk memperoleh data dalam proses pembangunan model.

Hasil realisasi/konstruksi model PMBP adalah uraian lebih detail (pengembangan) dari hasil rancangan model yang menghasilkan draft produk (model) yaitu: (1) buku model; (2) buku siswa; (3) lembar kerja siswa (LKS); (4) RPP; dan (5) instrumen-instrumen penelitian pengembangan. 
Dalam penilaian kevalidan model dan komponen-komponen model (buku siswa, LKS, RPP) dilakukan oleh tujuh ahli yang teridiri dari lima dosen pendidikan matematika dan dua guru matematika, sedangkan untuk menilai kepraktisan dan keefektifan model dilakukan uji coba model di SMP Wahid Hasyim Malang kelas delapan. Hasil penilaian model PMBP menunjukkan bahwa buku model dan komponen-komponennya (buku siswa, LKS, RPP) telah memenuhi kriteria produk model yang valid, praktis dan efektif.

Implementasi model PMBP dilakukan dengan desain eksperimen "desain kelompok kontrol pretest-posttest random" (the randomized pretest-posttest control group design), yang menunjukkan bahwa model PMBP berpengaruh positif terhadap hasil pembelajaran matematika dan hasil pembelajaran dengan model PMBP lebih baik daripada dengan model konvensional.

Hasil kajian pengembangan model PMBP ini telah memenuhi kriteria kevalidan, kepraktisan dan keefektifan serta telah diimplementasikan. Untuk itu, model PMBP ini dapat dipertimbangkan sebagai alternatif model dalam pelaksanaan pembelajaran matematika topik persamaan linier dua variabel di SMP. Kepraktisan dan keefektifan model ini terbatas pada materi matematika topik persamaan linier dua variabel untuk siswa kelas delapan SMP. Oleh karena itu, terdapat peluang untuk para peneliti untuk melaksanakan kajian kepraktisan dan keefektifan model pada siswa kelas delapan yang sama dengan bagian yang berbeda atau mengenai kelas dan bagian kajian yang berbeda.

\section{DAFTAR PUSTAKA}

Arends, R. (2007). Learning to teach. Terjemahan oleh Helly Prajitno Soetjipto. 2008. Yogyakarta: Pustaka Siswa.

Arifin, Z. (2012). Penelitian pendidikan, metode dan paradigma baru, penelitian pengembangan. Bandung: PT Remaja Rosdakaya.

Arikunto, S. (2009). Dasar-dasar evaluasi pendidikan. Jakarta: PT Bumi Aksara.

Allsopp, D. H., Keyger, M. M., \& Lovin, L. D. (2007). Teaching mathematiks meaningfully: solution for reaching struggling learners. Paul. H. Brookes Publishing. London.

Atsnan, M. F. \& Gazali, R. (2013). Penerapan pendekatan scientific dalam pembelajaran matematika SMP kelas VII materi bilangan (pecahan). Prosiding Seminar Nasional Matematika, Jurusan Pendidikan Matematika FMIPA Universitas Negeri Yogyakarta, Yogyakarta, 9 November 2013. (P.429-436)

Borg, W. R. \& Gall, M.D. (1989). Educational research: an introduction. London: Longman, Inc.

Budimansyah, D. (2002). Model pembelajaran dan penilaian portofolio. Bandung: PT Genesindo.

Budimansyah, D. (2012). Perancangan pembelajaran berbasis karakter. Bandung: Widya Aksara Press.

Budiningsih, A. C. (2005). Belajar dan pembelajaran. Jakarta: PT Rineka Cipta. 
Chance, P. (1986). Thinking in the classroom: A survey of programs. New York: Teachers College, Columbia University.

Creswell, J. W. (2009). Research design; qualitative, quantitative and mixed methods approaches. Thousand Oaks, California: Sage.

Dahar, W. R. (2011). Teori-teori belajar dan pembelajaran. Jakarta: Erlangga.

Depdikbud. (2012a). Daftar rata-rata kabupaten/kota Hasil Ujian Nasional 2011/2012

Jenjang SMP. Diakses dari http://118.98.234.22/sekretariat/hasilun/index.php/smp.

Depdikbud. (2012b). TIMSS (Trends in International Mathematics and Science Study) 2011.

Diakses dari http://litbang.kemdikbud.go.id/index.php/survei-internasional-timss.

Depdiknas. (2003). Undang-Undang Republik Indonesia Nomor 20 Tahun 2003 tentang

Sistem Pendidikan Nasional. Jakarta: Dediknas.

Eggen, P. \& Kauchack, D. (2012). Srategy and models for teachers: teaching content and thinking skills (Strategi dan model pembelajaran: mengajarkan konten dan ketrampilan berpikir). Jakarta: Indeks.

Eggen, P., \& Kauchak, D. (2007). Educational psychology: windows on classrooms (7th ed). Upper Saddle River, NJ: Perason.

Fajar, A. (2009). Portofolio dalam pembelajaran IPS. Bandung: Remaja Rosdakarya.

Glasersfeld, V. (1996). Introduction: Aspects of constructivism. In C. T. Fosnot (Ed.), Constructivism: Theory, perspectives, and practice. New York: Teachers Colleg Press.

Grinnell, R. M. (1988). Social work research and evaluation. Springfield: F.E. Peacock Publishers, Inc.

Hierbert, J. \& Carpenter, T. P. (1992). Learning and teaching with understanding. In D. A. Grouws (Ed.). Handbook of Research on Mathematics Teaching and Learning. Old Tappan, NJ: Macmillan.

Hudoyo, H. (2005). Kapita selekta pembelajaran matematika. Malang: UM Press.

http://www.diknas.malangkota.go.id

Jacobsen, D. A., Eggen, P. \& Kauchak, D. (2009). Methods for teaching: Promoting student learning in K-12 classrooms. Upper Saddle River, New Jersey: Pearson Education.

Joyce, B. \& Weil, M. (2009). Models of teaching. New Jersey USA: Pearson Education, Inc, Publishing as Allyn \& Bacon.

Johnson, E. B. (2002). Contextual teaching and learning: What it is and why it is here to stay. California USA: Corwin Press. Inc.

Johnson, D. W. \& Johnson, R.T. (2006). Learning together and alone: Cooperation, competition, and individualzation (8th ed). Needham Heights, MA: Allyn \& Bacon.

Karso. (2008). Pendidikan matematika I. Jakarta: Universitas Terbuka.

Kemendikbud. (2013a). Peraturan Menteri Pendidikan dan Kebudayaan Republik Indonesia Nomor 65 tahun 2013 tentang Standar Proses Pendidikan Dasar dan Menengah. Jakarta: Kemendikbud. 
Kemendikbud. (2013b). Peraturan Menteri Pendidikan dan Kebudayaan Republik Indonesia Nomor 81A tahun 2013 tentang Implementasi Kurikulum. Jakarta: Kemendikbud.

Kemendikbud. (2013c) . Materi pendidikan dan pelatihan profesi guru 2013. Jakarta: Kemendikbud.

Kemendikbud. (2013d). Materi pelatihan guru implementasi Kurikulum 2013 SMP/MTs matematika. Jakarta: Badan Pengembangan Sumber Daya Manusia Pendidikan dan Kebudayaan dan Penjaminan Mutu Pendidikan (BPSDMP dan PMP) Kemendikbud.

Kemendikbud. (2014). Peraturan Menteri Pendidikan dan Kebudayaan Republik Indonesia Nomor 160 tahun 2014 tentang Pemberlakuan Kurikulum tahun 2006 dan Kurikulum 2013. Jakarta: Kemendikbud.

Kilpatrick, J., Swafford, J. \& Findell, B. (Eds). (2001). Adding it up: Helping children learn mathematics. Washington DC: National Academy Press.

Komalasari, K. (2010). pembelajaran kontekstual: Konsep dan aplikasi. Bandung: Refika Aditama

MacKinnon, G. R. (2004). Why model sometimes fail. Eight Suggestions to Improve Science Instruction. Journal of College Science Education, 78, 1162-1163.

Malang Post. 2011. Hasil Ujian Nasional Sekolah Menengah Pertama Malang Raya. 2 Juni 2011.

Marpaung, Y. (2003). Perubahan paradigma pembelajaran matematika di sekolah. Makalah disajikan dalam Seminar Nasional Pendidikan Matematika di Universitas Sanata Darma. Tanggal 27-28 Maret 2003. Yogyakarta: Universitas Sanata Darma.

McCombs, B. \& Miller, L. (2007). Learner-centered classroom practices and assessment. Thousand Oaks, CA: Corwin.

Moleong, L. J. (2012). Metodologi penelitian kualitatif. Bandung: PT Remaja Rosdakarya.

Miles, B. W \& Huberman, A. M. (1986). Qualitative data analysis: a sourcebook of new methods. Beverly Hills: Sage Publications.

Muhsetyo, G. (2008). pembelajaran matematika SD. Jakarta: Universitas Terbuka.

Mulyasa, E. (2013). Pengembangan dan implementasi Kurikulum 2013. Bandung: PT Remaja Rosdakarya

Muslich, M. (2009). KTSP pembelajaran berbasis kompetensi dan kontekstual. Jakarta: Bumi Aksara.

National Council of Teachers of Mathematics (NCTM). (2000). Principles and standards for school mathematics. Reston, VA: National Council of Teachers of Mathematics.

Nieveen, N. (1999). Prototyping to reach product quality. In Jan Van den Akker, R.M Branch, K. Gustafson, N. Nieveen, \& Tj. Plomp. Design approaches and tools in education and training. Dordrecht: Kluwer Academic Publisher.

Saad, N. S. \& Ghani, S. A. (2010). Teaching mathematics in secondary schools: theories and practices. Tanjong Malim: Universiti Pendidikan Sultan Idris.

Pambudi, D. S. (2007). Berbagai alternatif model dan pendekatan dalam pembelajaran 
matematika. Jurnal Pendidikan Matematika. Vol. 1 (2): 39-45.

Plomp, T. (1997). Educational and training systems design: Introduction. Enschede: University of Twente, Faculty of Educational Science and Technology Enschede.

Riyanto, Y. (2009). Paradigma baru pembelajaran: Sebagai referensi untuk pendidik dalam implementasi pembelajaran yang efektif dan berkualitas. Jakarta: Kencana Prenada Media Group.

Rizali, A., Djati, I. \& Dharma, S. (2009). Dari guru konvensional menuju guru profesional. Jakarta: Grasindo.

Rochmad. (2012). Desain model pengembangan perangkat pembelajaran matematika. Jurnal Kreano. Vol. 3 (1): 59-72. Diakses dari http://journal.unnes.ac.id/nju/index.php/kreano/article.

Rusman. (2012). Model-model pembelajaran mengembangkan profesionalisme guru. Jakarta: PT Raja Grafindo Persada.

Sa'dijah, C. (2013). Kepekaan bilangan siswa smp melalui pembelajaran matematika kontekstual yang mengintegrasikan keterampilan berpikir kreatif. Jurnal Pendidikan dan pembelajaran Universitas Negeri Malang, Vol. 20 (2): 222-227.

Sanjaya, W. (2008). Perencanaan dan desain sistem pembelajaran. Jakarta: Kencana.

Sanjaya, W. (2006). pembelajaran dalam implemenatsi kurikulum berbasis kompetensi. Jakarta: Kencana.

Santoso, S. (2009). Panduan lengkap menguasai statistik dengan SPSS 19.0. Jakarta: PT Elex Media Komputindo.

Slavin, R. E. (2011). Educational psychology: theory and practise. Upper Saddle River, New Jersey: Pearson Education, Inc.

Soedjadi, R. (2003). Pemanfaatan realitas dan lingkungan dalam pembelajaran matematika. Surabaya: Unesa.

Soedjadi, R. (2010). Kiat pendidikan matematika di indonesia. Jakarta: Dirjen Dikti Depdikbud.

Sugiyono. (2011). Metode penelitian kombinasi (mixed methods). Bandung: Alfabeta.

Sugiyono. (2013). Metode penelitian kuantitatif, kualitatif dan $R \& D$ (Reasearch and Development). Bandung: Alfabeta.

Suherman, E. (2001). Strategi pembelajaran matematika kontemporer. Bandung: JICA UPI.

Sujiono, Y. N. (2010). Mengajar dengan portofolio. Jakarta: PT Indeks.

Sukmadinata, N. S. (2012). Metode penelitian pendidikan (Penelitian memberikan deskripsi, eksplanasi, prediksi, inovasi, dan juga dasar-dasar teoritis pengembangan pendidikan; penelitian dan pengembangan / $R \& D)$. Bandung: PT Remaja Rosdakarya.

Suparno, P. (2010). Filsafat konstruktivisme dalam pendidikan. Yogyakarta: Kanisius.

Suparno, P. (2012). Teori perkembangan koginitif jean Piaget. Yogyakarta: Kanisius. 
Suprihatiningrum. (2012). Strategi pembelajaran: teori dan aplikasi. Yogyakarta: Er-Ruzz Media.

Suyono. (2012). Belajar dan pembelajaran; Teori dan konsep dasar. Bandung: PT Remaja Rosdakarya.

Syamsuri, I. \& Ibrohim. (2011). Lesson study (Studi pembelajaran). Malang: UM Press.

Trianto. (2011). Mendesain model pembelajaran inovatif-progresif. Jakarta: Kencana Prenada Media Group.

Turmudi. (2009a). Landasan filsafat dan teori pembelajaran matematika (Berparadigma eksploratif dan investigatif). Jakarta: PT Leuser Cita Pustaka.

Turmudi. (2009b). Taktik dan strategi pembelajaran matematika (Referensi untuk guru matematika seri 2). Jakarta: PT Leuser Cita Pustaka.

Vygotsky, L. (1978). Mind in society. Cambridge: Harvard University Press.

Walle, J. A. V. D. (2012). Elementary and middle school mathematics. Terjemah oleh Suyono: Matematika Sekolah Dasar dan Menengah; Pengembangan Pengajaran. Jakarta: Erlangga.

Widoyoko, E. P. (2012). Teknik penyusunan instrumen penelitian. Yogyakarta: Pustaka Siswa.

Winter, R. (1989). Learning from experience: Principles and practice in action-reseach. Philadelphia: The Falmer Press.

Yamin, M. (2012). Desain baru pembelajaran konstruktivistik. Jakarta: Referensi

Yaumi, M. (2013). Prinsip-prinsip desain pembelajaran, disesuaikan dengan kurikulum 2013. Jakarta: Kencana. 